\title{
POTENCY OF AGRICULTURAL WASTE FOR FORAGE IN TOBASA REGENCY
}

\author{
${ }^{1} \mathrm{M}$. Adelina and ${ }^{2} \mathrm{~S}$. Kisno \\ ${ }_{1,2}$ Del Institute of Technology, North Sumatera, Indonesia
}

\begin{abstract}
Forage, which is provided by environment, is one of the important factors to consider in animal husbandry since the productivity of the livestock is $70 \%$ affected by environment rather than genetic factor whilst 60 up to $80 \%$ of cost production is allocated for producing and providing forage. In addition, the grazing land which simultaneously functions as the green resources for animal feed is getting lesser and lesser. In Tobasa regency, North Sumatera, Indonesia, the land used for farming is about 22,685 hectares which are used by the local people for growing paddy, cacao, corn, coffee, and other agricultural products. The waste produced as the result of these agricultural and farming activities can be used as animal feed or forage. This research aims to explore the efforts in reducing agricultural waste and utilize it as forage through fermentation process (ammonization and molasses) as the solution to the forage issues such as low nutrition and rough-fibred substance. The result of this research is expected to fulfill the needs of alternative animal feed and protecting the environment through diminishing agriculture waste.
\end{abstract}

Keywords: forage, agricultural waste, fermentation, livestock

\section{INTRODUCTION}

Referring to the national long term development plan of Indonesia 2005-2025 and to maintain the continuance of the projects have been developed five years before, the development of information and technology is aimed at supporting some sectors. One of the sectors is food which aims to realize the independent, prosperous, and justice people of Indonesia. Nowadays, the utilization of technology in the community is still limited due to some factors. One of the factors is the lack of efficient technological use which can be implemented in managing natural resources. This problem has effect on the waste handling which are as the result of the natural waste. The continual increase amount of waste without proper handling will lead to new environmental issues and indeed it will affect the living thing.

Sitoluama village is situated on Laguboti district in Toba Samosir regency in North Sumatera. Most of the people here works in agricultural sector and one of the favorable dominant commodity here is coffee. There are two types of coffee here; they are Robusta and Arabica. 


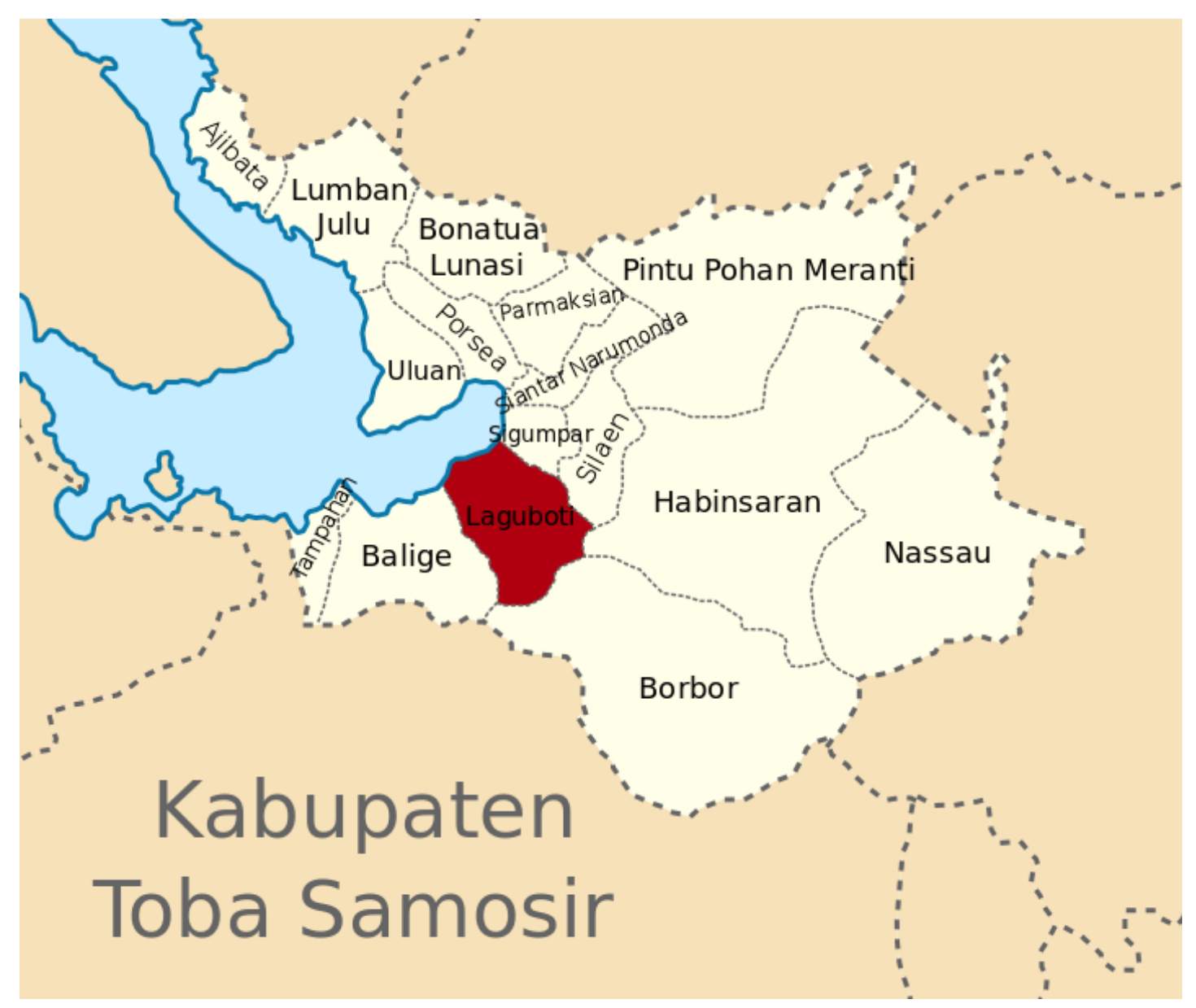

Figure 1. Implementation Area in Sitoluama Village - Laguboti District (www.tobasamosirkab.go.id, 2016)

The problem aroused from this agricultural sector is the waste produced since most people only use the coffee bean while other parts of coffee are only waste. The waste is getting much and much everyday due to the people knowledge limitation in processing the waste to be useful materials in life.

The potency of the wet process waste rind has big opportunity since the waste rind of the coffecy is physically has $48 \%$ mass of the total weight of the wet fruit. This leads to do more efforts on utilizing the coffee waste rind as an effort to benefit the people and to preserve the environment. One of these efforts is by utilizing the waste as the materials for forage since this effort will help the agricultural sector in providing more resources for forage due to the green area as the raw materials have ben lesser and lesser and this will provide alternative materials for feeding the animal. This project aims to overcome the problem of overloading coffee rind waste amount through processing it as the raw material for forage. Moreover, this project objective is to help the cattleman in providing food for their cattle.

\section{EXPERIMENTAL}

To solve the existing problem as the result of increasing amount of coffee rind waste, the researchers try to provide a solution by utilizing the waste as the forage. The result of the implementation will help the coffee farmers and cattleman in increasing the life of the people in Sitoluama. 


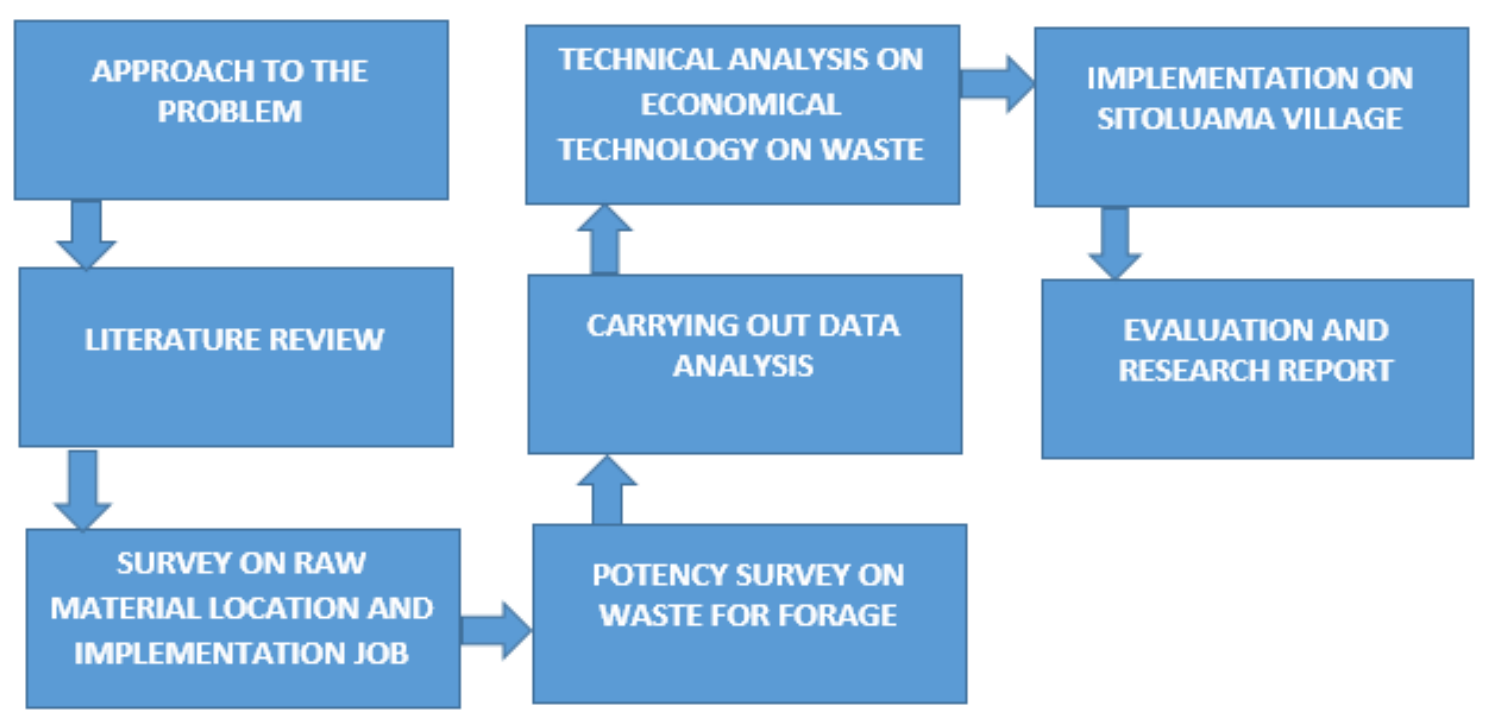

Figure 2. Project Scope Scheme

At this time, the coffee waste is left intake and it pollutes the environment. Seeing the big chance of the amount of coffee rind waste, a technology is needed to process it. There are some drawbacks if the waste is directly given to feed the animal such as the content of the protein is relatively low, the highly raw fiber content which contains the substance obstructing the animals' growth and the high content of water inside the waste which makes it easy to decay.

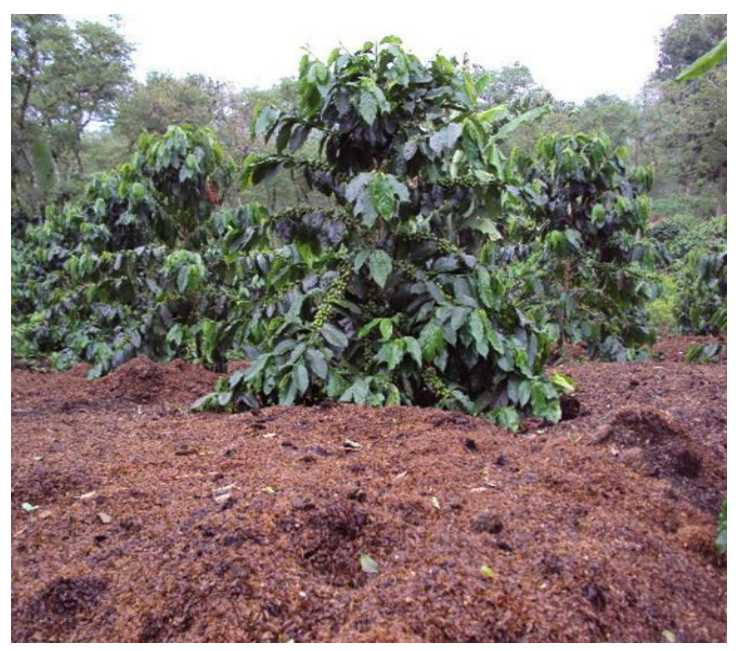

Figure 3. Coffee Rind Waste (www.kompasiana.com, 2015)
To overcome those issues, some processes can be conducted to increase the quality of the nutrition and to lengthen the storage period.

Some steps in the production process are: fermentation, drying, drilling, packaging, and safekeeping. Fermentation aims to produce the quality of the nutrition and reduce the substance level which obstructs the digestive process in the cattle (Enari, 1983). Guntoro et al (2006) declared that fermentation with Aspergillus niger could increase the protein content from $7.9 \%$ up to $12.41 \%$ and it can be used as the proper animal food. This result can replace bran as the important component in forage both for ruminant and non-ruminant animals.

First, Aspergillus niger is activated by sterilized clean water, added by sugar, urea, and NPK. The composition to make 10 liters of Aspergillus niger are 10 liters water 100 grams sugar, 100 gr urea, 50 grams NPK and 100 grams Aspergillus niger. All these materials are dissolved in the clean container and they are well stirred. Then, aeration process is conducted with aerator for 24-36 hours. The readyfermented coffee rind waste is spread on a $5-10 \mathrm{~cm}$ thickness medium and poured with Aspergillus niger solvent. Flushing can be carried out with sprayer and the stack of the waste is covered with a clean plastic cover for 4-5 days. Next, the drying process can be done through under-sun drying or using dryer aiming 
to stop fermentation process and to ease the drilling process and to extend storage period. Drying is carried out until the water level comes at $12-14 \%$ which marked by texture change becoming hard and the color becomes blackened. Drilling is carried out to obtain softer texture (like powder) to make it easily consumed by the animals. The efficient drilling can be done through drilling machine so that the form and size of the powder is adjustable. This powder as the result of waste processing can be directly given to feed the animal or stored in the period of 6-10 months. To keep the quality in good condition and to avoid early decay, this powder must be well packaged. Packaging can be carried out using a wellsealed plastic container to avoid insects or harmful microorganism. All these processing must be implemented through training for the farmers both in class and practical session. The effectivity of the training can measured through conducting pre-test and post-test.

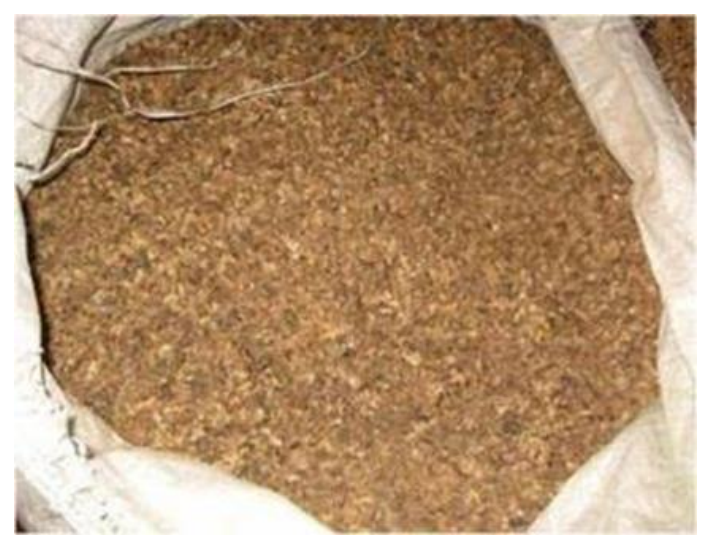

Figure 4. Forage form Coffee Rind Waste (www.litbang.pertanian.go.id, 2015)

\section{REFERENCES}

Anonymous. Kecamatan Laguboti. http://www.tobasamosirkab.go.id/wilayah. Accessed in 2015

Anonymous. Limbah Kulit Buah Kopi. www.kompasiana.com. Accessed in 2015.

Enari, T.M. (1983). Microbial Cellulase. In Microbial Enzyme and Biotechnology. Edited W.M. Fogarty. Applied Science Publishing. New York.

Guntoro, S. (2006). Petunjuk Teknis Pengolahan Limbah Perkebunan Untuk Pakan. Balai Pengkajian Teknologi Pertanian (BPTP). Bali. Denpasar.

Guntoro, S. (2008). Membuat Pakan Ternak Dari Limbah Perkebunan. Agromedia Pustaka. Jakarta.

Guntoro, et al. (2006). Pengaruh Pemberian Limbah Mete Olahan terhadap Pertumbuhan Kambing. Prosiding Seminar Nasional Teknologi Peternakan dan Veteriner Puslitbang. Badan Litbang Pertanian. Bogor.

Anonymous. Pakan Ternak dari Limbah Kulit Buah Kopi. www.litbang.pertanian.go.id. Accessed in 2015 